\title{
KAITAN KONSUMSI SAYUR DAN MINUM MINUMAN BERKARBONASI TERHADAP KEJADIAN OBESITAS PADA REMAJA DI MYANMAR
}

\section{VEGETABLE AND SOFTDRINK CONSUMPTION RELATED TO OBESITY AMONG ADOLESCENT IN MYANMAR}

\author{
Purwo Setiyo Nugroho ${ }^{*}$, Helena S. Andriana ${ }^{2}$ \\ 1,2 Fakultas Kesehatan Masyarakat, Universitas Muhammadiyah Kalimantan Timur, \\ Jl. Ir. H Juanda No. 15 Kota Samarinda, Kalmantan Timur, Indonesia \\ *Email : purwo.skm@umkt.ac.id
}

\begin{abstract}
Obesity is one problem in developing country. Many factors related to obesity that need to intevention for increasing the obesity prevalence. This study aimed to analyze the habit of not eating vegetables and consuming carbonated drinks on the incidence of obesity in adolescents. This study used quantitative research methods with a cross-sectional design approach. The number of respondents was 2,838 school children in grades 7-11 aged 11-18 years in Myanmar, Which were taken by total sampling technique. The data collection that is used in this study was secondary data obtained from the Global School-Based Students Health Survey (GSHS) Myanmar in 2016. The study showed that there was a significant relationship between the risk of not eating vegetables (0.025) and no significant relationship between the consumption of carbonated drinks (0.225) and the incidence of obesity in adolescents. The results of the study can be used as an information and initial data sources for further research on the risk of not eating vegetables and consuming carbonated drinks in adolescents
\end{abstract}

Keyword : Obesity; Vegetable Consumption; Carbinated Drink; Adolescent

\begin{abstract}
ABSTRAK
Obesitas merupakan salah satu masalah di negara berkembang. Banyak faktor yang menyebabkan obesitas sehingga perlu untuk di intervensi dalam rangka penuurunan prevalens obesitas. Untuk menganalisis resiko kebiasaan tidak makan sayur dan konsumsi minuman-minuman berkarbonasi terhadap kejadian obesitas pada remaja. Penelitian ini menggunakan metode penelitian kuantitatif dengan pendekatan desain Cross Sectional. Jumlah responden sebanyak 2.838 anak sekolah kelas 7-11 yang berusia 11-18 tahun di Myanmar. Teknik pengambilan sampel dengan Total sampling. Pengambilan data pada penelitian ini menggunakan data sekunder yang diperoleh dari Global School-Based Students Health Survey (GSHS) Myanmar tahun 2016. Penelitian menunjukan adannya hubungan yang signifikan antara resiko kebiasaan tidak makan sayur $(0,025)$ dan tidak ada hubungan yang signifikan antara konsumsi minuman-minuman berkarbonasi $(0,225)$ dengan kejadian obesitas pada remaja. Hasil studi dapat dimanfaatkan sebagai informasi dan sumber data awal untuk penelitian selanjutnya mengenai resiko kebiasaan tidak makan sayur dan konsumsi minuman-minuman berkarbonasi pada remaja.
\end{abstract}

Kata Kunci: Obesitas; Sayur; Minuman Berkarbonasi; Remaja 


\section{PENDAHULUAN}

Obesitas merupakan faktor risiko yang tidak menguntungkan bagi tubuh manusia, karena dapat meningkatkan daya tahan tubuh terhadap insulin, sehingga glukosa dalam darah tidak dapat dimetabolisme dengan baik oleh sel ((1). prevalensi obesitas saat ini berada diperingkat ke 5 yang menjadi penyebab kematian utama didunia, pada tahun 2016 angka kematian diseluruh dunia baik negara berkembang maupun maju akibat obesitas diperkirakan sebesar 4,5 juta kematian (2). Obesitas disebabkan oleh adanya ke tidak seimbangan antara masukan energi dengan kekurangan energi, ini merupakan tren yang meningkat di banyak negara berkembang (3). menurut survei nasional 2009 di Asia Tenggara, Prevalensi obesitas 25,38\%, Dewasa 6,8\%. diantara 1019 anak dan remaja di Asia tenggara, Prevalensi obesitas adalah 7,6\%. Seperti yang kita semua tahu, $80 \%$ remaja mengalami obesitas sampai mereka menjadi gemuk saat dewasa (4). Berdasarkan data dari GSHS telah menunjukan prevalensi remaja yang tidak mengkonsumsi sayur itu $89 \%$ dan remaja yang mengkonsumsi minumanminuman berkarbonasi sebesar $44,9 \%$ (5). Pada survei yang telah dilakukan pada tahun 2013-2014 rata-rata konsumsi sayur pada remaja 2,2 $(0,1)$ dan $1,2(0,1)$ porsi/hari sementara porsi ini tidak sesuai dengan rekomendasi asupan harian sayuran menurut WHO sejumlah $\geq 5$ porsi (400 g) (6).Dalam survei ini hampir separuh siswa melaporkan mengonsumsi minuman ringan berkarbonasi satu kali atau lebih per hari dan proporsi yang sama $(46,4 \%)$ WHO merekomendasikan pembatasan gula gratis hingga kurang dari $10 \%$ dari total asupan energi sebagai bagian dari diet sehat, dan pembatasan lebih lanjut hingga 5\% untuk manfaat kesehatan tambahan (7).

\section{BAHAN DAN METODE}

Metode penelitian yang dilakukan yaitu metode penelitian kuantitatif, desain Penelitian yaitu analitik korelasi dengan pendekatan Cross Sectional adalah data yang dikumpulkan pada satu priode tertentu pada beberapa objek dengan tujuan untuk menggambarkan keadaan. (8). Penelitian ini menggunakan data sekunder yang diperoleh langsung dari Global School-based Student Health Survei (GSHS) Myanmar 2016. Analisis data menggunakan Chi Square untuk menganalisis besarnya odds ratio variabel bebas dan terikat. Penelitian ini melibatkan anak sekolah kelas 7-11 yang berusia 13-18 tahun. Desain sampel cluster dua tahap digunakan untuk menghasilkan data yang mewakili semua siswa di kelas 7-11 di Myanmar. Populasi berasal dari bahasa inggris yaitu population yang berarti jumlah penduduk (8), Populasi pada penelitian ini ialah Remaja yang ada di negara Myanmar yaitu sebanyak 2.838 yang di ambil dari jumlah keseluruhan populasi dapat dilihat pada survei GSHS tahun 2016 di Myanmar (5).

\section{HASIL DAN PEMBAHASAN}

\section{Analisis Univariat}

Tabel 1. Karakteristik Responden

\begin{tabular}{lll}
\hline Variabel & $\mathrm{n}$ & $\%$ \\
\hline Usia & & \\
11 tahun & 15 & 6 \\
12 tahun & 218 & 8.6 \\
13 tahun & 511 & 20.3 \\
14 tahun & 636 & 25.2 \\
15 tahun & 601 & 23.8 \\
16 tahun & 406 & 16.1 \\
17 tahun & 110 & 4.4 \\
18 tahun & 26 & 1.0 \\
Jenis Kelamin & & \\
Laki-Laki & 1127 & 44,7 \\
Perempuan & 2523 & 55,3 \\
Tingkatan Kelas & & \\
7 pendidikan menengah & 586 & 23,2 \\
8 pendidikan menengah & 463 & 18,4 \\
9 pendidikan menengah & 670 & 26,6 \\
10 pendidikan menengah & 801 & 31,7 \\
11 Pendidikan menengah & 3 & 1 \\
Tidak Mengkonsumsi Sayur & & \\
Tidak Makan & 35 & 1,4 \\
Ya Makan & 2488 & 98,6 \\
Mengkonsumsi Minuman- & & \\
Minuman Berkarbonasi & & \\
Ya Minum & 1071 & 42,4 \\
Tidak Minum & 1452 & 57,6 \\
Penderita Obesitas & & \\
Obesitas & 49 & 1,9 \\
Tidak Obesitas & 2474 & 98,1 \\
\hline Total & $\mathbf{2 5 2 3}$ & $\mathbf{1 0 0}$ \\
\hline & & \\
& &
\end{tabular}

Bedasarkan Tabel 1 diatas dapat dilihat bahwa dari 2.523 responden berdasarkan rentang usia responden berada pada usia 11-18 tahun dengan 
responden terbanyak pada kelas 10 sebanyak 801 responden $(31,7 \%)$. Berdasarkan tingkat kelas menunjukan responden terbanyak pada kelas 10 sebanyak 801 responden $(31,7 \%)$. Berdasarkan jenis kelamin menunjukan responden terbanyak pada perempuan sebanyak 1396 responden (55,3\%). Berdasarkan responden terbanyak pada mengonsumsi sayur selama 30 hari sebelum sebanyak 2488 responden (98,6\%). Berdasarkan responden terbanyak pada tidak mengkonsumsi minuman-minuman berkarbonasi satu atau lebih perhari selama 30 hari sebelum sebanyak 1452 responden $(57,6 \%)$. Serta Berdasarkan menunjukan responden terbanyak pada tidak penderita obesitas sebanyak 2474 responden $(98,1 \%)$.

\section{Analisis Bivariat}

Tabel 2. Hubungan Tidak memakan sayur dan Minuman-Minuman Berkarbonasi Terhadap Obesitas pada Remaja di Negara Myanmar

\begin{tabular}{|c|c|c|c|c|c|c|c|}
\hline \multirow[b]{2}{*}{ Variabel } & \multicolumn{2}{|c|}{ Status Gizi } & \multirow[b]{2}{*}{ Total } & \multirow[b]{2}{*}{ P-Value } & \multirow[b]{2}{*}{ OR } & \multicolumn{2}{|c|}{ CI 95\% } \\
\hline & Obesitas & $\begin{array}{c}\text { Tidak } \\
\text { Obesitas }\end{array}$ & & & & Lower & Upper \\
\hline Tidak Memakan Sayu & & & & & & & \\
\hline Ya & 46 & 2442 & 2488 & 0,025 & 4,977 & 1,471 & 16,838 \\
\hline Tidak & 3 & 32 & 35 & & & & \\
\hline $\begin{array}{l}\text { Mengkonsumsi Minu } \\
\text { Minuman Berkarbona }\end{array}$ & & & & & & & \\
\hline Ya & 25 & 1046 & 1071 & 0,220 & 1,422 & 0,808 & 2,504 \\
\hline Tidak & 24 & 1428 & 1452 & & & & \\
\hline
\end{tabular}

\section{PEMBAHASAN}

\section{Hubungan Tidak Makan Sayur Terhadap} Obesitas pada Remaja di Negara Myanmar

Berdasarkan tabel 2 diatas dapat dilihat bahwa 2523 responden terdapat 46 responden yang makan sayur selama 30 hari sebelum survey dengan status gizi obesitas. Sedangkan 3 responden yang tidak makan sayur selama selama 30 hari sebelum survey dengan status gizi obesitas sebanyak 3 responden. Hasil dari Continuty correction menunjukan bahwa nilai $\mathrm{p}$-value yang didapatkan sebesar 0,025. Nilai tersebut lebih kecil dari taraf signifikansi a yaitu 0.05 yang artinya H0 ditolak, adanya hubungan antara tidak makan sayur terhadap obesitas pada remaja di negara Myanmar. Nilai Odds Ratio (OR) menunjukan hasil responden yang tidak makan sayur selama 30 hari sebelum survey mempunyai peluang 4.977 kali lebih tinggi untuk mengalami obesitas dibandingkan dengan yang makan sayur. Hasil Confidence Interval (CI) 95\% sebesar 1.47116.83, sehingga nilai CI melewati angka 1 berarti adanya hubungan dan faktor resiko antara tidak makan sayur terhadap obesitas pada remaja di negara Myanmar.

Penilitian ini sejalan dengan penelitian terdahulu yang memperoleh $\mathrm{p}=0,017$ dengan nilai $a=0,05$ dimana $p<a$ yang berarti $\mathrm{H} 0$ ditolak yang menujukan bahwa ada hubungan antara tidak makan sayur terhadap obesitas, dengan cofficient corelation 1,33 yang berarti hubungan positif kuat antara tidak makan sayur dengan obesitas yang memiliki arti semakin sering remaja tidak mengkonsumsi sayur maka mempengaruhi terjadinya obesitas (9). Buah dan sayuran merupakan makanan rendah kalori, kaya serat, vitamin, dan mineral untuk menjaga kesehatan. Rendahnya konsumsi buah dan sayuran pada anak dapat meningkatkan risiko obesitas. Makan buah dan sayuran dapat membantu menerapkan pola makan sehat untuk mengontrol dan mengatur berat badan karena rendah kalori, membantu menjaga sistem 
metabolisme tubuh untuk keseimbangan kadar gula, kolestrol dan memperlancar pencernaan, dalam jangka panjang sedikit konsumsi buah dan sayuran dapat menyebabkan penyakit kronis misalnya hipertensi, kanker, jantung koroner, diabetes, hipertensi dan obesitas (10).

Hubungan Minuman-Minuman Berkarbonasi Terhadap Obesitas pada Remaja di Negara Myanmar

Berdasarkan tabel 2 diatas dapat dilihat bahwa 2523 responden terdapat 25 responden yang mengkonsumsi minuman-minuman berkarbonasi satu hari atau lebih selama 30 hari sebelum survey dengan status gizi obesitas. Sedangkan responden yang tidak mengkonsumsi minuman-minuman berkarbonasi satu hari atau lebih selama 30 hari sebelum survey dengan status gizi obesitas sebanyak 24 responden. Hasil dari Continuty correction menunjukan bahwa nilai $p$-value yang didapatkan sebesar 0,220. Nilai tersebut lebih besar dari taraf signifikansi a yaitu 0.05 yang artinya $\mathrm{H} 0$ diterima, tidak adanya hubungan antara konsumsi minuman-minuman berkarbonasi terhadap obesitas pada remaja di negara Myanmar.

Penilitian ini sejalan dengan penelitian terdahulu yang memperoleh $\mathrm{p}=0,297$ dengan nilai $a=0,05$ dimana $p>a$ yang berarti H1 ditolak yang menunujukan bahwa tidak ada hubungan antara minuman-minuman berkarbonasi terhadap obesitas, dengan cofficient corelation 1,988 yang berarti tidak ada hubungan antara minumanminuman berkarbonasi dengan obesitas (11). Tidak adanya hubungan antara konsumsi minumanminuman berkarbonasi terhadap obesitas pada remaja dikarenakan obesitas tidak hanya disebabkan oleh konsumsi minuman-minuman berkarbonasi, tetapi juga dapat disebabkan oleh beberapa faktor yang dapat menyebabkan kegemukan yaitu, faktor genetik, faktor lingkungan , faktor demografi, dan faktor sosial kultura. faktor lingkungan (aktivitas fisik, konsumsi fast and food dan soft drink), faktor demografi (umur, jenis kelamin, dan ras/suku bangsa) dan faktor sosial kultura (ekonomi, tingkat pendidikan, dan media massa) (11).

\section{KESIMPULAN DAN SARAN}

Berdasarkan hasil penelitian yang telah dilakukan mendapatkan kesimpulan bahwa adanya hubungan tidak makan sayur $(\mathrm{p}=0.025$ Or $=4.977$ CI $=1.471-16.838$ ) dan tidak adanya hubungan antara minuman-minuman berkarbonasi $(p=0.280)$ terhadap obesitas pada remaja di negara Myanmar. Saran darin penelitian ini adalah dengan adanya penelitian ini dapat memberikan informasi pentingnya status gizi pada remaja serta meningkatkan kesadaran akan perbaikan gizi, bagi siswa/i diharapkan untuk selalu memperhatikan makanan yang akan dikonsumsi, memperbanyak makan sayur dan mengurangi konsumsi minumanminuman berkarbonasi. Bagi siswa/i dengan status gizi normal selalu menjaga pola makan dan makanan sehat seperti buah dan sayur agar mencapai tubuh gizi seimbang.

\section{UCAPAN TERIMAKASIH}

Terima kasih atas kerjasama antara dosen dan teman mahasiswa Universitas Muhammadiyah Kalimantan Timur (UMKT) yang telah mendukung serta membimbing penelitian ini. Serta orang tua dan rekan-rekan telah memberikan doa dan dukungannya

\section{DAFTAR PUSTAKA}

1. Nugroho PS, Fahrurodzi DS. Risiko obesitas terhadap diabetes melitus di Indonesia; studi data Indonesia family life survey V. J Publ Kesehat Masy Indones. 2018;5(3):103-6.

2. Mazidi M, Banach M, Kengne AP. Prevalence of childhood and adolescent overweight and obesity in Asian countries: A systematic review and meta-analysis. Arch Med Sci. 2018;14(6):1185-203.

3. UNICEF. Children in South East Asia face a 'double burden' of obesity and undernutrition, new report finds. https://doi.org/10.1111/obr.12605. 2016.

4. Goudet S, Hlaing LM, Griffiths PL. Exploring food security and nutrition among young women in the formally regulated garment sector of Myanmar. Ann N Y Acad Sci. 2020;1468(1):35-54.

5. World Health Organization. Myanmar- Global School-Based Student Healt Survey 2016. NCD Microdata Repository. 2016.

6. Kjøllesdal M, Htet AS, Stigum H, Hla NY, Hlaing $H H$, Khaine EK, et al. Consumption of fruits and vegetables and associations with risk factors for noncommunicable diseases in the Yangon region of 
Myanmar: a cross-sectional study. BMJ Open. 2016;6(8):e011649.

7. Rafiony A, Purba MB, Pramantara IDP. Konsumsi fast food dan soft drink sebagai faktor risiko obesitas pada remaja. J Gizi Klin Indones. 2015;11(4):170.

8. Siregar IS. Metode Penelitian Kuantitatif Dilengkapi Dengan Perbandingan Perhitungan Manual \& SPSS. Jakarta: Kencana Prenada Media Mandiri; 2013.

9. Al Rahmad AH. Keterkaitan Asupan Makanan dan Sedentari dengan Kejadian Obesitas Pada Anak Sekolah Da sar di Kota Banda Aceh. Bul
Penelit Kesehat. 2019;47(1):67-76.

10. Dewi Y. Persepsi dan Prilaku Makan Buah pada Anak Obesitas dan Orang Tua. J Ilm Mhs Univ Surabaya. 2013;2(1):1-17.

11. Drink S. Faktor Risiko Konsumsi Soft Drink dengan Kejadian Kegemukan pada Remaja di SMK Kristen Bala Keselamatan Palu Risk Factors of Soft Drink Consumption with Obviouness in Adolescents at Vocational School of Salvation Army , Palu Elvyrah Faisal *, Ridha Anayan. 2021;15(1):25-30. 